\title{
TIME-DRIVEN ACTIVITY-BASED COSTING TO ENSURE COMPETITIVENESS IN THE AGRICULTURAL MACHINERY SECTOR
}

\author{
M. B. Ceran, B. Yilmaz \\ 1 - Selcuk University, Konya, Turkey \\ 42075, Turkey, Konya, Alaaddin Keykubat Yerleskesi \\ e-mail: mbceran@selcuk.edu.tr,byilmaz@selcuk.edu.tr
}

\begin{abstract}
As a result of technological developments and international trade agreements, trade borders between countries have disappeared. Global competition resulting from global market strategies necessitates businesses to operate in an intense competitive environment. In today's economy, where the conditions of competition are constantly changing, enterprises need to gain competitive advantage over their competitors rather than survive in competition. The determination of the right costing method enables companies to get rid of unnecessary costs, increase their profitability, and gain success in international competition. As a result of technological developments, changes in production processes have accelerated the transition from labour intensive production to technology intensive production. Due to this change, traditional costing methods are insufficient to give accurate results in determining the true costs of businesses. For this need, modern costing systems are being developed. Activitybased costing, which is one of the modern costing systems, could not find enough application area due to its difficult and costly implementation. The timedriven activity-based costing system, which was inspired by activity-based costing but developed from a very different perspective, has found more application areas in enterprises. In this study, the hypothesis that time-driven activity-based costing gives more accurate results in determining and controlling operating costs of businesses, is investigated. A questionnaire is conducted to search for the applicability of this costing system in the agricultural machinery sector for providing competitive advantage.
\end{abstract}

Key words: competitive advantage, time-driven activity-based costing, agricultural machinery sector.

As a result of technological developments and changes in international trade agreements, the demarcation of trade boundaries between countries and the global competition resulting from the global market strategies of the enterprises necessitate the

(C) Ceran M.B., Yilmaz B., 2019 
companies to operate in an intense competitive environment. In today's economy, where the conditions of competition are constantly changing, enterprises need to provide competitive superiority to their competitors rather than survive in competition and develop targets such as sustainability of their competitiveness. It is obligatory for enterprises to take the measures that will enable them to reach these targets and to provide the appropriate working environment for necessary changes to happen.

Activity-based costing (ABC), which was developed to replace the volume-based and traditional cost systems and to eliminate their deficiencies, is based on the fact that general production expenses are generated by activities that consume resources, and that these activities are used by cost elements such as semi-finished products, finished goods and services. The activity-based costing system (ABC), which is defined as a strategic cost method aimed to provide accurate determination of the costs of enterprises, was developed by scientists of United States of America and the first company to implement this system was John Deere, also a USA company operating in the agricultural machinery sector.

Cost is defined as the total value in which all the factors that the enterprises endure to obtain the goods or services included in their field of activity which are expressed in money [1]. In today's highly competitive economy, reducing costs in production processes has become an important goal for all businesses. The low-cost strategy aims to increase profits by reducing production costs, despite the fact that prices are set equal or closer to the prices of competing enterprises [2]. "Cost", also known as one of the competitive priorities, is of great importance for enterprises to compete with their competitors in a global competitive environment and to ensure sustainable competition. In order to be successful in the market against their competitors, businesses must have a sustainable cost understanding and develop their cost strategies accordingly.

Controlling costs enables enterprises to identify unnecessary costs and offers the opportunity to carry out the necessary works to reduce or eliminate these unnecessary costs. Unplanned costs cannot be controlled, and this causes enterprises inability in calculating their costs accurately. It is important that the methods to be used in cost planning and control provide accurate results. Traditional costing methods are inadequate in the face of different production methods and applications brought about by environmental and technological conditions. In this context, it is seen that the lately developed costing methods are useful in accurate costing calculations.

The main reason for the emergence of costing and cost distribution problems are the insufficiency and unreliability of information provided by traditional cost accounting systems in all important decisions on cost surges. As a result of growing criticism against traditional costing systems and increased cost pressure resulting from intense competition forced scientists towards analysis of the reasons behind the cost formation [3]. This is done by strategic cost management. Strategic cost management is defined as helping to formulate and communicate strategies, conduct tactics that implement these strategies, and then develop and implement controls that follow success in achieving strategic objectives [4].

TDABC obtains resource cost information from departments in the enterprise from the system, it mainly calculates the cost per unit time of each resource (eg. labor cost per 
minute). The total cost of production of the product or service is calculated by multiplying the time of the product or service and the unit resource costs [5]. In this context, the costs of the products or services and the costs of the activities used in their production are calculated on the basis of actual capacity utilization and the idle capacity is recorded separately.

In order to determine whether the businesses operating in the agricultural machinery sector can accurately calculate their costs, the existing costing systems they have been using and the applicability of TDABC in the agricultural machinery sector, 106 enterprises operating in the sector were included in the research. Business executives participated in the survey were interviewed face-to-face with the advantage of participation in the Konya Agricultural Fair, which has an important place in the agricultural machinery sector.

In line with objectives and assumptions of the study, a survey was conducted to obtain quantitative data. The questionnaire was constructed as a face to face interview. The reasons for choosing face to face interviews was the fact that Konya Agricultural Fair, in which the major agricultural machinery manufacturers were participating to a great extent, was being held in a suitable period in terms of time and cost advantage.

402 companies participated in Konya Agriculture Fair in 2017. However, it was determined that only 319 of these enterprises were directly producing agricultural machinery. During the fair, 121 of 319 enterprises were met with. Since 15 of them didn't have any managers to answer the questionnaire, only 106 enterprises are interviewed at the end.

Hypothesis 1: According to the legal structure of the enterprise, there is no difference between the applicability of the TDABC system in the agricultural sector.

Hypothesis 2: The applicability of TDABC in the agricultural sector does not change according to firm scale (number of personnel).

Hypothesis 3: There is a significant relationship between capital stock (equity) and the applicability of TDABC in the agricultural sector.

Hypothesis 4: There is a relationship between the annual production and the applicability of TDABC in the agricultural sector.

Table 1

Table 2

Legal Structure of Enterprises

\begin{tabular}{|l|c|c|}
\hline & Frequency & Percentage \\
\hline $\begin{array}{l}\text { Sole } \\
\text { proprietorship }\end{array}$ & 40 & 37,7 \\
\hline $\begin{array}{l}\text { Joint stock } \\
\text { company }\end{array}$ & 66 & 62,3 \\
\hline Total & 106 & 100,0 \\
\hline
\end{tabular}

\section{Workforce}

\begin{tabular}{|l|c|c|}
\hline & Frequency & Percentage \\
\hline Below 50 & 71 & 67,0 \\
\hline $50-100$ & 31 & 29,2 \\
\hline $101-200$ & 3 & 2,8 \\
\hline Above 200 & 1 & 0,9 \\
\hline Total & 106 & 100,0 \\
\hline
\end{tabular}


The statistical analysis package program SPSS 15 was used for statistical analysis and evaluation of the data obtained from the questionnaire. Accordingly, the findings over the answers given to the survey questions directed to the enterprises are as follows.

\section{Equity of Enterprises}

Table 3

\begin{tabular}{|l|c|c|}
\hline & Frequency & Percentage \\
\hline $\begin{array}{l}\text { Under 500 } \\
\text { Thousand TL }\end{array}$ & 3 & 2,8 \\
\hline $\begin{array}{l}\text { 500 Thousand - } \\
1 \text { Million TL }\end{array}$ & 11 & 10,4 \\
\hline 1-2 Million TL & 33 & 31,1 \\
\hline 2-5 Million TL & 33 & 31,1 \\
\hline $\begin{array}{l}\text { 5-10 Million } \\
\text { TL }\end{array}$ & 15 & 14,2 \\
\hline $\begin{array}{l}\text { Above 10 } \\
\text { Million TL- }\end{array}$ & 11 & 10,4 \\
\hline Total & 106 & 100,0 \\
\hline
\end{tabular}

Table 4

Total Number of Yearly Production of

Enterprises

\begin{tabular}{|l|c|c|}
\hline & Frequency & Percentage \\
\hline Below 50 & 4 & 3,8 \\
\hline $50-500$ & 11 & 10,4 \\
\hline $501-1000$ & 24 & 22,6 \\
\hline $1001-5000$ & 49 & 46,2 \\
\hline $5001-10.000$ & 15 & 14,2 \\
\hline $\begin{array}{l}\text { Above } \\
10.000\end{array}$ & 3 & 2,8 \\
\hline Total & 106 & 100,0 \\
\hline
\end{tabular}

Table 5

Importance of Concepts for Enterprises

\begin{tabular}{|c|c|c|c|c|c|c|c|c|}
\hline & & $\begin{array}{c}\text { Not } \\
\text { Impor- } \\
\text { tant }\end{array}$ & $\begin{array}{c}\text { A } \\
\text { Little } \\
\text { Impor } \\
\text { tant }\end{array}$ & $\begin{array}{c}\text { Somew } \\
\text { hat } \\
\text { Impor- } \\
\text { tant }\end{array}$ & $\begin{array}{c}\text { Impor- } \\
\text { tant }\end{array}$ & $\begin{array}{c}\text { Very } \\
\text { Impor- } \\
\text { tant }\end{array}$ & Mean & $\begin{array}{c}\text { Standard } \\
\text { Deviation }\end{array}$ \\
\hline \multirow[t]{2}{*}{ Price } & $\mathrm{F}$ & 0 & 0 & 4 & 28 & 74 & \multirow[t]{2}{*}{4,66} & \multirow[t]{2}{*}{0,55} \\
\hline & $\%$ & 0 & 0 & 3,8 & 26,4 & 69,8 & & \\
\hline \multirow[t]{2}{*}{ Quality } & $\mathrm{F}$ & 0 & 0 & 3 & 27 & 76 & \multirow{2}{*}{4,69} & \multirow{2}{*}{0,52} \\
\hline & $\%$ & 0 & 0 & 2,8 & 25,5 & 71,7 & & \\
\hline \multirow[t]{2}{*}{ Cost } & $\mathrm{F}$ & 0 & 0 & 2 & 29 & 75 & \multirow[t]{2}{*}{4,69} & \multirow[t]{2}{*}{0,51} \\
\hline & $\%$ & 0 & 0 & 1,9 & 27,4 & 70,8 & & \\
\hline \multirow[t]{2}{*}{ Variety } & $\mathrm{F}$ & 1 & 20 & 31 & 14 & 40 & \multirow[t]{2}{*}{3,68} & \multirow[t]{2}{*}{1,20} \\
\hline & $\%$ & 0,9 & 18,9 & 29,2 & 13,2 & 37,7 & & \\
\hline \multirow{2}{*}{$\begin{array}{l}\text { Trustfull } \\
\text { ness }\end{array}$} & $\mathrm{F}$ & 0 & 14 & 23 & 12 & 57 & \multirow[t]{2}{*}{4,06} & \multirow[t]{2}{*}{1,14} \\
\hline & $\%$ & 0 & 13,2 & 21,7 & 11,3 & 53,8 & & \\
\hline $\begin{array}{l}\text { Distribu- } \\
\text { tion }\end{array}$ & $\mathrm{F}$ & 4 & 24 & 33 & 17 & 28 & \multirow[t]{2}{*}{3,39} & \multirow[t]{2}{*}{1,21} \\
\hline $\begin{array}{l}\text { Perfor- } \\
\text { mance }\end{array}$ & $\%$ & 3,8 & 22,6 & 31,1 & 16,0 & 26,4 & & \\
\hline
\end{tabular}




\section{Specified Criteria in Determining Annual Production Program}

\begin{tabular}{|l|c|c|c|}
\hline \multicolumn{2}{|c|}{} & Yes & No \\
\hline \multirow{2}{*}{ Demand } & $\mathrm{F}$ & 106 & 0 \\
\cline { 2 - 4 } & $\%$ & 100,0 & 0 \\
\hline Production Capacity & $\mathrm{F}$ & 106 & 0 \\
\cline { 2 - 4 } & $\%$ & 100,0 & 0 \\
\hline \multirow{3}{*}{ Competitors } & $\mathrm{F}$ & 87 & 19 \\
\cline { 2 - 4 } & $\%$ & 82,1 & 17,9 \\
\hline \multirow{3}{*}{ Top Management Decisions } & $\mathrm{F}$ & 47 & 59 \\
\cline { 2 - 4 } & $\%$ & 44,3 & 55,7 \\
\hline Production Planning & $\mathrm{F}$ & 75 & 29,2 \\
\cline { 2 - 4 } & $\%$ & 70,8 & 48 \\
\hline Financial Resource Status & $\mathrm{F}$ & 58 & 45,3 \\
\cline { 2 - 4 } & $\%$ & 54,7 & \\
\hline
\end{tabular}

Methods Used in Production Costing

\begin{tabular}{|l|c|c|c|}
\hline & Frequency & \% within group & Factor Percentage, \% \\
\hline Balance Sheets & 87 & 29,3 & 82,1 \\
\hline Income Statement & 73 & 24,6 & 68,9 \\
\hline $\begin{array}{l}\text { Source and Disposition } \\
\text { Statement }\end{array}$ & 13 & 4,4 & 12,3 \\
\hline Cost of Sold Goods & 26 & 8,8 & 24,5 \\
\hline Cost Analysis & 98 & 33,0 & 92,5 \\
\hline Total & 297 & 100,0 & 280,2 \\
\hline
\end{tabular}

\section{Cost Items Used in Production Costing}

Table 8

\begin{tabular}{|l|c|c|}
\hline & Frequency & Percentage \\
\hline Direct Materials + Direct Labor & 3 & 2,8 \\
\hline $\begin{array}{l}\text { Direct Materials + Direct Labor + General } \\
\text { Production Costs }\end{array}$ & 75 & 70,8 \\
\hline $\begin{array}{l}\text { Direct Materials + Direct Labor + General } \\
\text { Production Costs + General Management Costs }\end{array}$ & 27 & 25,5 \\
\hline $\begin{array}{l}\text { Determination of Sales Price First, Costing } \\
\text { Accordingly }\end{array}$ & 1 & 0,9 \\
\hline
\end{tabular}


Table 9

Distribution of General Production Costs over Other Cost Items

\begin{tabular}{|l|c|c|c|}
\hline & Frequency & $\%$ within group & $\begin{array}{c}\text { Factor Percentage, } \\
\%\end{array}$ \\
\hline Direct Materials & 44 & 13,8 & 41,5 \\
\hline Direct Labor & 59 & 18,5 & 55,7 \\
\hline Direct Labor Hour & 73 & 22,9 & 68,9 \\
\hline Machinery Working Hour & 80 & 25,1 & 75,5 \\
\hline Production Amount & 43 & 13,5 & 40,6 \\
\hline Activity-Based Distribution & 1 & 0,3 & 0,9 \\
\hline $\begin{array}{l}\text { Direct Costs (Direct Materials and } \\
\text { Labor) }\end{array}$ & 19 & 6,0 & 17,9 \\
\hline Total & 319 & 100,0 & 300,9 \\
\hline
\end{tabular}

Table 10

Knowledge about Cost Management Techniques

\begin{tabular}{|l|c|c|c|}
\hline \multicolumn{2}{|c|}{} & Have Knowledge & $\begin{array}{c}\text { Do not Have } \\
\text { Knowledge }\end{array}$ \\
\hline \multirow{3}{*}{ Standard Costing } & $\mathrm{F}$ & 102 & 4 \\
\cline { 2 - 4 } & $\%$ & 96,2 & 3,8 \\
\hline \multirow{3}{*}{ Phase Costing } & $\mathrm{F}$ & 89 & 17 \\
\cline { 2 - 4 } & $\%$ & 84 & 16 \\
\hline \multirow{3}{*}{ Order Costing } & $\mathrm{F}$ & 85 & 21 \\
\cline { 2 - 4 } & $\%$ & 80,2 & 19,8 \\
\hline \multirow{3}{*}{ Activity-Based Costing } & $\mathrm{F}$ & 2 & 104 \\
\cline { 2 - 4 } & $\%$ & 1,9 & 98,1 \\
\hline Time-Driven Activity-Based Costing & $\mathrm{F}$ & 1 & 105 \\
\cline { 2 - 4 } & $\%$ & 0,9 & 99,1 \\
\hline Target Costing & $\mathrm{F}$ & 76 & 30 \\
\cline { 2 - 4 } & $\%$ & 71,7 & 28,3 \\
\hline Kaizen Costing & $\mathrm{F}$ & 31 & 75 \\
\cline { 2 - 4 } & $\%$ & 29,2 & 70,8 \\
\hline
\end{tabular}


Table 11

Views on the Importance of Existing Costing Methods in Specified Areas

\begin{tabular}{|c|c|c|c|c|c|c|c|c|}
\hline & & $\begin{array}{l}\text { Not } \\
\text { Impor } \\
\text { tant }\end{array}$ & $\begin{array}{c}\text { A Little } \\
\text { Impor- } \\
\text { tant }\end{array}$ & $\begin{array}{l}\text { Some- } \\
\text { what } \\
\text { Impor- } \\
\text { tant }\end{array}$ & $\begin{array}{c}\text { Impor } \\
\text {-tant }\end{array}$ & $\begin{array}{c}\text { Very } \\
\text { Impor- } \\
\text { tant }\end{array}$ & Mean & $\begin{array}{l}\text { Standard } \\
\text { Deviation }\end{array}$ \\
\hline \multirow{2}{*}{$\begin{array}{l}\text { Costing of } \\
\text { Direct } \\
\text { Material }\end{array}$} & $\mathrm{F}$ & 0 & 1 & 8 & 28 & 69 & \multirow{2}{*}{4,56} & \multirow{2}{*}{0,68} \\
\hline & $\%$ & 0 & 0,9 & 7,5 & 26,4 & 65,1 & & \\
\hline \multirow{2}{*}{$\begin{array}{l}\text { Costing of } \\
\text { Direct Labor }\end{array}$} & $\mathrm{F}$ & 0 & 1 & 8 & 30 & 67 & \multirow{2}{*}{4,54} & \multirow{2}{*}{0,68} \\
\hline & $\%$ & 0 & 0,9 & 7,5 & 28,3 & 63,2 & & \\
\hline \multirow{2}{*}{$\begin{array}{l}\text { Costing of } \\
\text { General } \\
\text { Production } \\
\text { Costs }\end{array}$} & $\mathrm{F}$ & 1 & 12 & 26 & 24 & 43 & \multirow{2}{*}{3,91} & \multirow{2}{*}{1,10} \\
\hline & $\%$ & 0,9 & 11,3 & 24,5 & 22,6 & 40,6 & & \\
\hline \multirow{2}{*}{$\begin{array}{l}\text { Determination } \\
\text { of Product } \\
\text { Prices }\end{array}$} & $\mathrm{F}$ & 0 & 11 & 22 & 24 & 49 & \multirow{2}{*}{4,05} & \multirow{2}{*}{1,04} \\
\hline & $\%$ & 0 & 10,4 & 20,8 & 22,6 & 46,2 & & \\
\hline \multirow{2}{*}{$\begin{array}{l}\text { Investment } \\
\text { Decisions }\end{array}$} & $\mathrm{F}$ & 1 & 13 & 29 & 25 & 38 & \multirow{2}{*}{3,81} & \multirow{2}{*}{1,08} \\
\hline & $\%$ & 0,9 & 12,3 & 27,4 & 23,6 & 35,8 & & \\
\hline
\end{tabular}

Table 12

Views on the Importance of TDABC

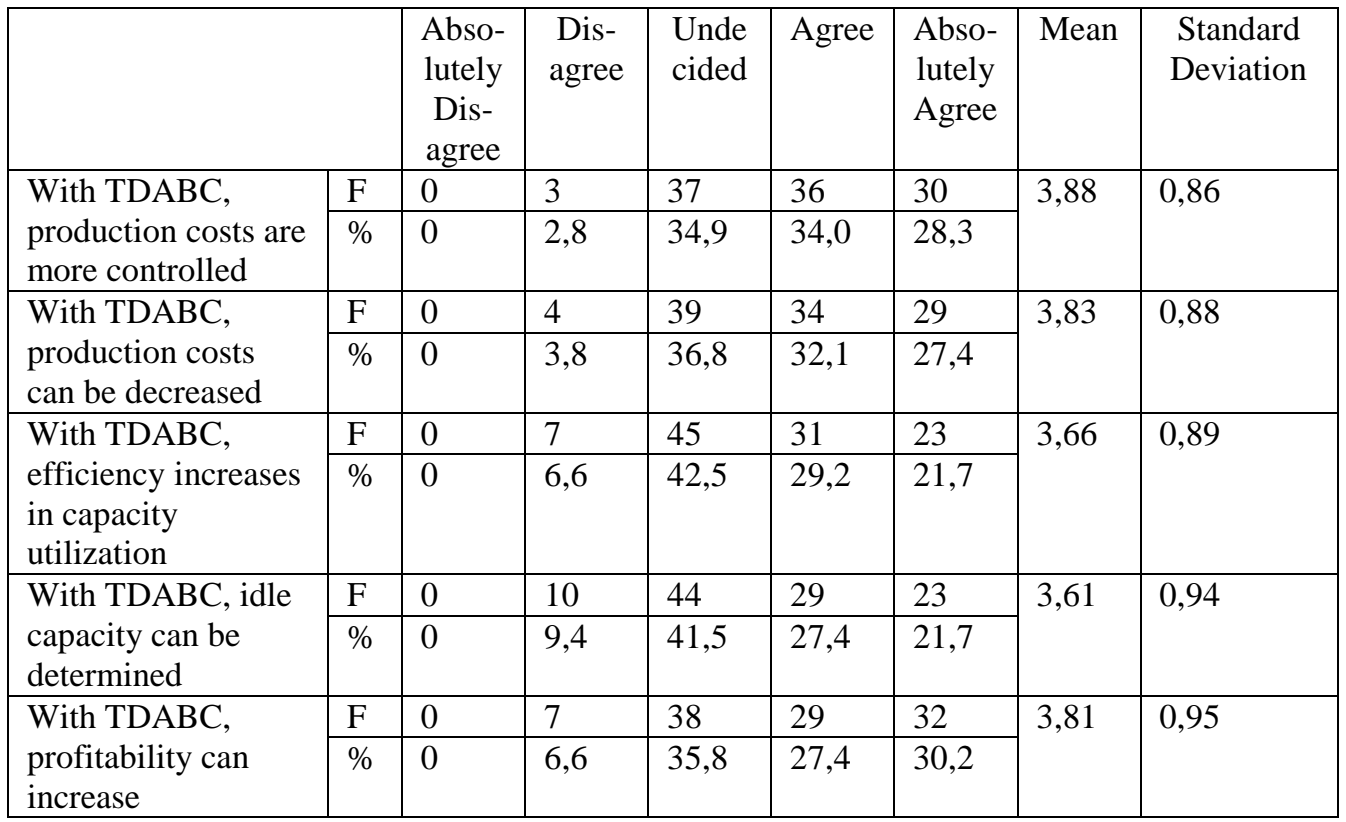


In order to better analyze the results of the survey, some hypotheses have been produced. According to these hypotheses, chi-square tests were applied to the survey results. These hypotheses and their results are shown below.

Hypothesis 1: "There is no significant difference between the applicability of TimeDriven Activity-Based Costing System in agricultural sector according to the legal structure of the enterprise."

According to the findings; $27,5 \%$ of business executives think that TDABC is applicable, while $36,4 \%$ of joint stock company executives think that TDABC is applicable. It was found out from chi-square test that managers think that there is no significant difference regarding the applicability of the Time-Driven Activity-Based Costing System depending on the legal structures of enterprises (x2: 3,023, df: 2, p: 0,222).

Hypothesis 2: "The applicability of TDABC in the agricultural sector does not significantly change according to the scale of the firm (number of personnel)."

According to the findings; while $23,9 \%$ of enterprises with less than 50 employees think that TDABC is applicable, $36,4 \%$ of enterprises with 50 or more employees think that Time-Driven Activity-Based Costing System is applicable. It was found out from chisquare test that there is a difference between the opinions of managers about the applicability of TDABC depending on the number of personnel of their enterprises $(\mathrm{x} 2$ : 9,554, df: 2, p: 0,009). There is a weak link between the managers' opinion on the applicability of TDABC and the number of staff in their businesses (Cramers V: 0,300, p: $0,009)$. When the number of personnel of the enterprise is known, it can predict managers' opinions on the applicability of TDABC by $6.5 \%$ (Goodman \& Kruskal Tau: 0,065, p: 0,001).

Hypothesis 3: "There is a significant relationship between capital size (equity) and the applicability of TDABC system in the agricultural sector."

According to the findings; $28,6 \%$ of managers of enterprises with a capital of less than 1 million Turkish Liras think that TDABC is applicable; and 65,4\% of the managers of enterprises with a capital of more than 5 million TL think that TDABC is applicable.

As a result of the chi-square test, it was found out that there is a difference between the opinions of managers about the applicability of TDABC depending on the capital stocks (equity) of the enterprises (x2:23,948, df: 6, p: 0,001). There is a weak link between managers' views on the capital stock of their businesses and the applicability of TDABC (Cramers V: 0,336, p: 0,001). When capital stock of the enterprise is known, it can predict the managers' opinion on the applicability of TDABC by 27,1\% (Lambda:0,271, p:0,003).

Hypothesis 4: "There is a significant relationship between the annual product output and the applicability of TDABC in the agricultural sector."

According to the findings; while 33,3\% of managers of enterprises with less than 500 annual product output think that TDABC is applicable, $33,3 \%$ of managers from enterprises with 500 to 1000 annual product output, $18,4 \%$ of managers from enterprises with 1001 to 5000 product output, $72,2 \%$ of managers from enterprises with more than 5000 product output think that TDABC is applicable. 
As a result of chi-square test, it was found out that there is a difference between the opinions of managers about the applicability of TDABC depending on the annual amount of finished product (x2:21,081, df: 6, p: 0,002). There is a weak link between the manager's opinion on applicability of TDABC and the annual product amount of his company (Cramers V: 0,315, p: 0,001). When annual product quantity of an enterprise is known, managers' opinions can be predicted on applicability of TDABC by $20.8 \%$ (Lambda:0,208, p:0,010).

Table 13

Results of Hypotheses

\begin{tabular}{|c|c|}
\hline $\begin{array}{c}\text { There is no significant difference } \\
\text { between the applicability of TDABC } \\
\text { according to the legal structure of the } \\
\text { enterprise. }\end{array}$ & $\begin{array}{l}\text { Chi-square test suggests no difference } \\
\text { between opinions of managers regarding } \\
\text { applicability of TDABC depending on legal } \\
\text { structures of businesses. }\end{array}$ \\
\hline $\begin{array}{l}\text { The applicability of TDABC in } \\
\text { agricultural machinery sector does not } \\
\text { significantly change according to the } \\
\text { scale of the firm (number of personnel). }\end{array}$ & $\begin{array}{l}\text { There is a weak link between the managers' } \\
\text { opinion on the applicability of TDABC and } \\
\text { the number of staff in their businesses. }\end{array}$ \\
\hline $\begin{array}{c}\text { There is a significant relationship } \\
\text { between capital size and applicability of } \\
\text { TDABC in agricultural machinery } \\
\text { sector. }\end{array}$ & $\begin{array}{c}\text { There is a weak link between managers' } \\
\text { views on the capital stock of their } \\
\text { businesses and the applicability of TDABC. }\end{array}$ \\
\hline $\begin{array}{c}\text { There is a significant relationship } \\
\text { between annual production and } \\
\text { applicability of TDABC in agricultural } \\
\text { machinery sector. }\end{array}$ & $\begin{array}{c}\text { There is a weak link between the managers' } \\
\text { opinion on the applicability of TDABC and } \\
\text { the amount of finished products of their } \\
\text { businesses. }\end{array}$ \\
\hline
\end{tabular}

In today's global competitive environment where competition is constantly changing with developing technology, businesses need to develop competitive superiority over their competitors and sustain their competitiveness. It is an obligation for enterprises to take the measures that will enable them to reach these targets, to provide appropriate working environment for necessary changes to take place inside the enterprise, and to achieve success.

Businesses should consider all processes and decisions, including pricing and costing, on a global scale and revise them in line with the requirements of the era. However, it is not possible for companies to have effect in pricing decisions and determine sales prices under international competition. For this reason, today, many enterprises have turned to the concept of costing in which they can directly intervene and provide efficiency. The determination of the right costing method enables the company to get rid of unnecessary costs, increase its profitability, and be successful in international competition. 
In this study, a survey was conducted to obtain quantitative data in order to determine the level of costing system usage in agricultural machinery sector and cost calculation mentality of enterprises in this sector. With this perspective, it is tried to be determined whether the enterprises operating in the agricultural machinery sector can accurately calculate their costs, which existing costing systems they have been using, and the level of applicability of time-driven activity-based costing system in the agricultural machinery sector. Managers of 106 enterprises which are operating in this sector has been interviewed face-to-face while they participate in 2017 Konya Agricultural Fair, which has an important place in the agricultural machinery sector. In conclusion of the four hypotheses developed for the survey, it is seen that traditional costing systems are used largely in the agricultural machinery sector. It has been found out that many of the enterprises ignore indirect costs in the calculation of costs or reflect them on product costs using their own traditional methods.

\section{Literature}

1. Avder E. Maliyet Muhasebesi / E. Avder. - Trabzon. - 2012. - 352 p.

2. Doğan Ö. İ. Kalite Uygulamalarının İşletmenin Rekabet Gücüne Etkileri / Ö. İ. Doğan // Dokuz Eylül Ünv. SBE Dergisi, İzmir. - 2006. - Cilt: 2, Sayı:1.

3. Yüzbaşıŏglu N. İşletmelerde Stratejik Yönetim ve Planlama Açısından Stratejik Maliyet Yönetimi ve Enstrümanları / N.Yüzbaşıŏlu // Selçuk Üniversitesi Sosyal Bilimler Enstitüsü Dergisi, Konya. - 2004. - Sayı:12.

4. Govindarajan V. Strategic cost management: tailoring controls to strategies / V.Govindarajan, J. K. Shank // Journal of Cost Management. - 1992. - Volume 6. Chapter 3.

5. Kaplan R. S. The Execution Premium: Linking Strategy to Operations for Competitive Advantage / R. S. Kaplan, D. P. Norton. - Harvard Business School Press, U. - (2008).

\section{References}

1. Avder, E. (2012). "Maliyet Muhasebesi”, Murathan Yayınevi, Trabzon.

2. Doğan, Ö. İ. (2006), “Kalite Uygulamalarının İşletmenin Rekabet Gücüne Etkileri”, Dokuz Eylül Ünv. SBE Dergisi, Cilt: 2, Sayı:1, İzmir.

3. Yüzbaşıŏlu, N. (2004), "İşletmelerde Stratejik Yönetim ve Planlama Açısından Stratejik Maliyet Yönetimi ve Enstrümanları", Selçuk Üniversitesi Sosyal Bilimler Enstitüsü Dergisi, Say1:12, Konya.

4. Govindarajan, V., Shank, J. K. (1992), "Strategic cost management: tailoring controls to strategies", Journal of Cost Management, Volume:6, Chapter:3.

5. Kaplan, R. S., Norton, D. P. (2008), "The Execution Premium: Linking Strategy to Operations for Competitive Advantage", Harvard Business School Press, U. 


\title{
ЧАСОВЕ ПРОЦЕСНО-ОРЕНТОВАНЕ УПРАВЛІННЯ ВИТРАТАМИ ДЛЯ ЗАБЕЗПЕЧЕННЯ КОНКУРЕНЦІЇ У СЕКТОРІ СІЛЬСЬКОГОСПОДАРСЬКОЇ ТЕХНІКИ
}

\author{
М. Б. Джеран, В. Їлмаз \\ 1 - Університет Сельчука \\ 42075, Туреччина, Коньї, Кампус Аладдін Кейкубат \\ e-mail:mbceran@selcuk.edu.tr,byilmaz@selcuk.edu.tr
}

Внаслідок технологічних розробок та міжнародних торговельних угод торгові кордони між країнами зникли. Глобальна конкуренція, що виникає внаслідок глобальних ринкових стратегій, зумовлює необхідність бізнесу працювати в інтенсивному конкурентному середовищі. У сучасній економіці, де умови конкуренції постійно змінюються, підприємствам потрібно здобувати конкурентну перевагу, а не виживати в конкурентній боротьбі. Визначення правильного методу калькуляції дає змогу компаніям позбутися зайвих витрат, підвищити свою прибутковість та отримати успіх у міжнародній конкуренції. В результаті технологічних розробок зміни виробничих процесів прискорили перехід від трудомісткого виробництва до технологічного виробництва. Через цю зміну традиційні методи калькуляції $\epsilon$ недостатніми, щоб дати точні результати у визначенні справжніх витрат бізнесу. Для цієї потреби розробляються сучасні системи обліку витрат. сс, яке є одним із сучасних систем калькуляції, не змогло знайти достатньо сфери застосування через іiі складну та затратну реалізацію. Часове процесно-орієнтоване управління витратами, яке було засноване на класичному процесно-орієнтованом управлінні, але розроблене 3 зовсім іншого погляду, знайшло більше областей застосування на підприємствах. У цьому дослідженні розглядається гіпотеза про те, що орієнтована на час калькуляція витрат дає більш точні результати при визначенні та контролі операційних витрат підприємств. Опитувальник проводиться для пошуку застосування цієї системи витрат у галузі сільськогосподарської техніки для забезпечення конкурентних переваг.

Ключові слова: конкурентна перевага, часове процесно-орієнтоване управління витратами, сектор сільськогосподарської техніки. 